\title{
Isolation and partial characterization of alginate extracted from Sargassum polycystum collected from three habitats in Banten, Indonesia
}

\author{
NIKEN DHARMAYANTI ${ }^{1,2, \bullet}$, JATNA SUPRIATNA ${ }^{1}$, ABINAWANTO $^{1}$, YASMAN ${ }^{1, \bullet \bullet}$ \\ ${ }^{1}$ Program of Conservation Biology, Department of Biology, Faculty of Mathematics and Natural Sciences, Universitas Indonesia. Jl. Lingkar UI, Depok \\ 16242, West Java, Indonesia. Tel.:+62-21-7270163, Fax.:+62-21-78829010, •vemail: yasman.si@ui.ac.id \\ ${ }^{2}$ Sekolah Tinggi Perikanan Jakarta. Jl. AUP Pasar Minggu, Jakarta Selatan 12520, Jakarta, Indonesia. Tel.:+62-21-7806874, \\ •email: niken.stp@gmail.com
}

Manuscript received: 30 April 2019. Revision accepted: 31 May 2019

\begin{abstract}
Dharmayanti N, Supriatna J, Abinawanto, Yasman. 2019. Isolation and partial characterization of Alginate from Sargassum polycystum of Banten, Indonesia. Biodiversitas 20: 1776-1785. The utilization of Sargassum polycystum as an alternative alginate source may reduce the dependence on alginate import as currently alginate demands in Indonesia are 100\% supplied from overseas. The purpose of this study was to characterize alginate extracted from Sargassum polycystum obtained from three locations with different ecological characteristics. Isolation of alginate was conducted through partial hydrolysis to separate guluronic acid and mannuronic acid followed by freeze-drying and then the parameters were measured qualitatively and quantitatively using FTIR. The results showed that alginate extracted from Sargassum polycystum collected from Lima Island, Ujung Kulon and Binuangeun were 11.48\%, 18.62\%, and $5.75 \%$, respectively with the viscosity were $35 \mathrm{cP}, 62.50 \mathrm{cP}$, and $81.33 \mathrm{cP}$, respectively. The test result of partial hydrolysis of alginate showed that guluronic block (GG) in the alginate polymer of Lima Island, Ujung Kulon and Binuangeun were 67.60\%, 59.00\%, and $41.40 \%$, respectively. These relate to the nature of the gel formed. The alginate from Lima Island tends to be more rigid and less flexible than that from Ujung Kulon and Binuangeun. The findings of this study suggest that there are differences in the concentration of the components of mannuronate and guluronate of Sargassum polycystum across different locations in Banten, Indonesia.
\end{abstract}

Keywords: Alginate, characteristics, partial hydrolysis, Sargassum polycystum

\section{INTRODUCTION}

Brown algae are known as alginate sources. Alginate, an anionic heteropolysaccharide extracted from natural brown algae, has useful properties for the food, chemical, medical, and agricultural industries (Inoe 2018). Alginate is needed in various industries for various purposes including as gelling agent, stabilizer, emulsifier, suspending agent and dispersing agent. In food industry, alginate compounds are added as ingredient in butter, ice cream, and milk. In cosmetics industry, it functions as water binder so that the cosmetic components are perfectly bound and easily penetrate skin tissue.

Alginophyte is a family of brown seaweeds. The difference in the main chemical compounds contained in seaweed shows the characteristics of the seaweed, suggesting different extraction process among seaweeds. Similarly, the benefits and uses of these chemical compounds also vary one another. These differences are caused by different species of seaweed, different location and growing season (Pereira 2018).

Alginate consists of group of polysaccharides and can be found in brown algae tissue. Alginate is a long chain polymer consisting of $\alpha$ - $(1 \rightarrow 4)$-linked L-guluronic acid (G) and $\beta$ - $(1 \rightarrow 4)$-linked D-mannuronic acid $(\mathrm{M})$. The content ratio $(\mathrm{G})$ and $(\mathrm{M})$ is referred to as the $\mathrm{G} / \mathrm{M}$ ratio. The $\mathrm{G} / \mathrm{M}$ ratio will greatly affect the quality of alginate in which the higher is the $\mathrm{G}$ content, the higher is the alginate thickness, and vice versa.

Although all brown algae contain alginate, only few species of brown algae are used commercially and can be found in subtropical climates such as Macrocystis pyrifera, Ascophyllum odosum, Laminaria hyperborea, Laminaria digitata, Ecklonia maxima, and Lessonia nigrescans. Whereas in Indonesia, the common species are Sargassum sp., Turbinaria sp., Hormophysa sp., and Padina sp. (Rasyid 2007). Alginophyte that grow in water consists of three genera, i.e., Sargassum with seven species, Turbinaria with two species, and Hormophisa.

Increasing demands on alginate require the enhancement of the quality of industry in which one of the aspects is encouraging the exploration of potential species as alginate sources. The alginate content of seaweed varies greatly depending on the species of brown seaweed extracted. For example, a study showed that brown macroalgae stocks found at Ekas Bay in Lombok Island vary across seasons and species. The biomass sourced from Padina reached $97.85 \pm 12.63$ and $79.54 \pm 2.53$ tons in May to June and November, respectively while Sargassaceae species produced $669.70 \pm 109.64$ and $147.70 \pm 77.97$ tons in May to June and November, respectively. The highest alginate yields were produced during the period May to June in which Padina can produce $9.10 \pm 0.06$ tons of dry alginate while Sargassum 
can produce $207.61 \pm 0.42$ tons of dry alginate. This study demonstrates that wild Sargassaceae is a potential source of alginate which is influenced by the ratio of mannuronate and guluronate (Setyawidati et al. 2018). Alginate formed in Sargassum cell walls reached $40 \%$ of the total dry weight and played an important role in maintaining the tissue structure of thallus. The thallus of Sargassum has a variety of shapes and sizes, ranging from in the form of rods and unite in a bundle to in the form of large thallus with outer shape like tall plants. The shape of the thallus can affect alginate content (Widyartini et al. 2017).

There is opportunity to increase alginate production in Indonesia to manage alginate resources sustainably but this will need information of Sargassum spp. and its contents. The genus of Sargassum consists of 400 species while in Indonesia there are 12 species namely Sargassum duplicatum, S. hitrix, S. echinocarpum, S. gracillinum, S. obtuspfolium, S. binderi, S. polycystum, S. microphylum, $S$. crassifolium, $S$ aquafolium, $S$. vulgare, and $S$. polyceratium.

Sargassum polycystum is an alginate-producing seaweed. So far, Sargassum polycystum grow wild and have not been cultivated in Indonesia. This study was aimed to obtain the ecological, morphological, molecular and structure of alginate extracted from Sargassum polycystum in western Java so that the relationship between genes from Sargassum and its structure can be revealed. This aim will be achieved through isolation and partial characterization of alginate extracted from Sargassum polycystum collected from Banten waters to identify the structure of sodium alginate based on the chemical composition of mannuronate and guluronate.

\section{MATERIALS AND METHODS}

\section{Study period and location}

The study was carried out in February 2018 until April 2019 in Banten Province (western Java), Indonesia. There were three sampling locations, i.e., Lima Island ( $6^{\circ} 00^{\prime} 05^{\prime}$ ' S, 10609'18" E), Ujung Kulon (6 $\left.6^{\circ} 48^{\prime} 15^{\prime \prime} \mathrm{S}, 105^{\circ} 29^{\prime} 5^{\prime \prime} \mathrm{E}\right)$, and Binuangeun (6 $\left.6^{\circ} 9^{\prime} 16^{\prime \prime} \mathrm{S}, 105^{\circ} 56^{\prime} 14^{\prime \prime} \mathrm{E}\right)$. The location of S. polycystum sampling is presented in Figure 1. The geographical conditions of western Java are surrounded by three major waters, i.e., the Java Sea in the north, the Sunda Strait in the west, and the Indian Ocean in the south.

\section{Sampling procedure}

Collection and identification of samples of Sargassum polycystum were conducted during the lowest tide at each study location. Samples were collected using transect method along the coast. Each sample was photographed and then taken to the Jakarta Fisheries University for identification and further analysis. Seaweed was stored in a plastic bag, cleaned, sorted according to genus, weighed in fresh condition, wind-dried, and then ready for alginate extraction and partial hydrolysis conducted in Chemistry Laboratory, Department of Fish Processing Technology, Jakarta Fisheries University, Jakarta, Indonesia. Analysis of functional group using FTIR (Fourier Transform Infrared Spectroscopy) was undertaken in Chemistry Laboratory, Department of Chemistry, University of Indonesia, Depok, Indonesia.

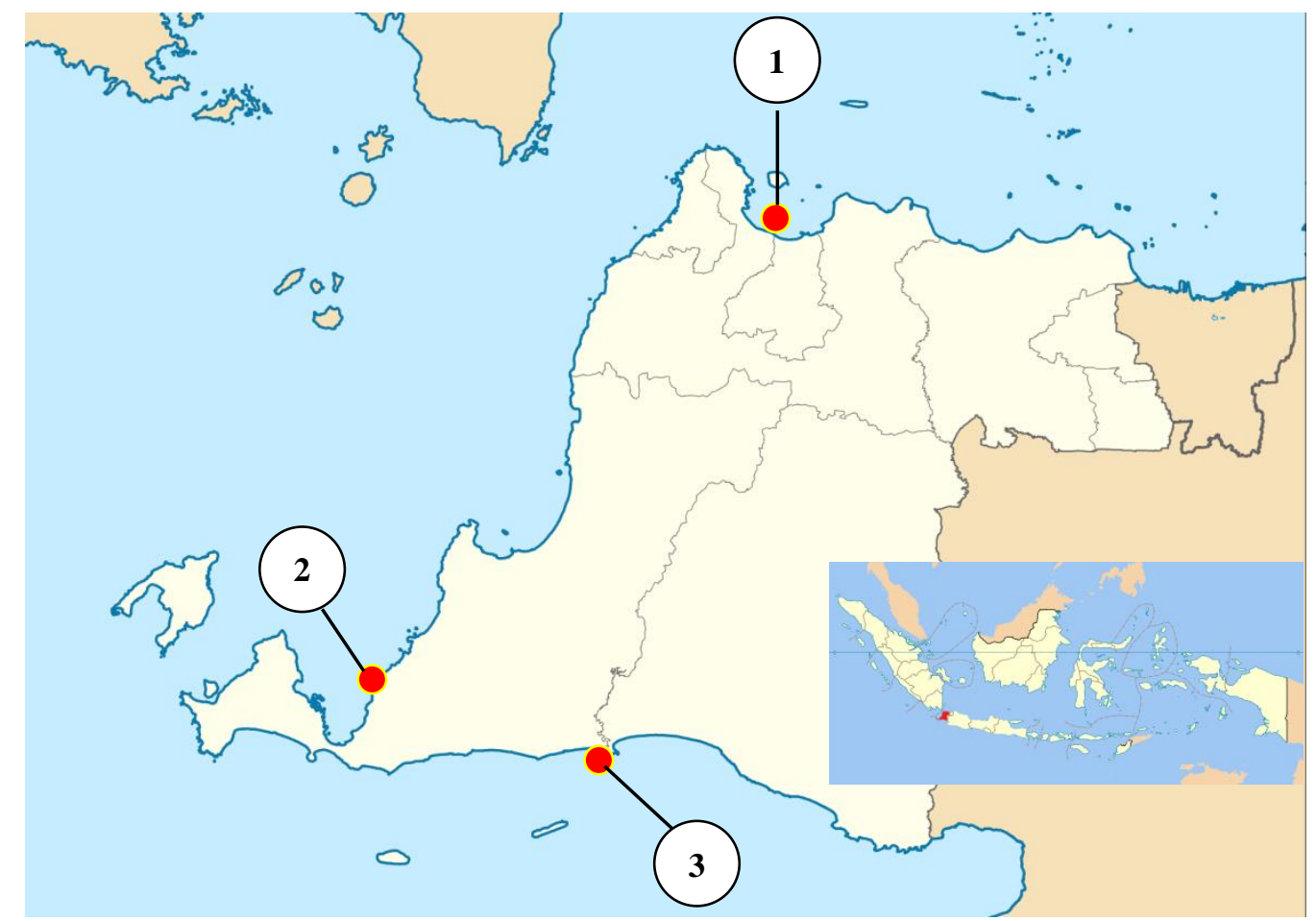

Figure 1. Three locations for sampling of Sargassum polycystum in Banten Province, Indonesia: 1. Lima Island; 2. Ujung Kulon; and 3. Binuangeun 


\section{Laboratory analysis}

Isolation and partial characterization of alginate from Sargassum polycystum included chemical composition of Sargassum polycystum, alginate extraction, characterization of alginate (i.e., rendement viscosity, water content, ash content, $\mathrm{pH}$ ), partial hydrolysis of alginate (i.e., isolation of mannuronic acid and guluronate acid, analysis of functional group analysis which is qualitatively proven on the FTIR curve).

\section{Materials and equipment}

Three samples of Sargassum polycystum from each location were prepared for extraction processes with materials included natrium carbonate, calcium chloride, chloride acid, alcohol $70 \%$, peroxide hydrogen, aquadest, $\mathrm{Ca}_{2} \mathrm{Cl}_{2} 4 \%, \mathrm{HCl} 2 \%, \mathrm{Na}_{2} \mathrm{CO} 34 \%, \mathrm{Ca}_{2} \mathrm{Cl}_{2} 10 \%, \mathrm{Ca}_{2} \mathrm{Cl}_{2}$ 5\%, HCl 5\%, dan Alkohol 95\%. Partial hydrolysis used $\mathrm{HCl} 37 \%$ and $\mathrm{NaOH} 5 \mathrm{~mol}$ and p.a grade chemicals for the analysis of alginate monomers. The equipment needed included equipment for alginate extraction, while the test equipment is the Brookfield brand viscometer, the Shimadzu Prestige Fourier Transform Infrared Spectroscopy (FTIR) and the Shimadzu Spectrophotometer.

\section{Data collection}

\section{Alginate extraction}

The extraction of alginate as follows: the raw material of Sargassum polycystum was cleaned, weighed at 200 grams then added with acetic acid solution according to the treatment. The mixed material was blended into seaweed pulp, heated at $80^{\circ} \mathrm{C}$ and stirred for 10 minutes. After that, it was filtered and squeezed into the form of coarse alginate liquid which was then dried at $65^{\circ} \mathrm{C}$ for 24 hours. After being dried it was then pressed to get coarse alginate flour.

\section{Na-alginate extraction process}

The main process of extracting Na-alginate was divided into four stages namely immersion (pre-extraction), extraction, bleaching, and purification. Immersion stage was carried out in an alkaline solution and an acid solution. Extraction was carried out in an alkaline atmosphere by cooking using extracting solutions $\left(\mathrm{Na}_{2} \mathrm{CO}_{3}, \mathrm{NaOH}\right)$. Bleaching used solution of $\mathrm{NaOCl}$ or $\mathrm{H}_{2} \mathrm{O}_{2}$. Purification was divided into three phases, i.e., the formation of alginic acid, the formation of sodium alginate and the formation of pure sodium alginate.

\section{Immersion}

Soaking seaweed in $\mathrm{CaCl}_{2}$ solution was aimed to dissolve laminarin, mannitol, dyes, and salts. This treatment also served to dissolve the remaining impurities in seaweed. According to Silva et al. (2015), alginic acid precipitated under the conditions of $\mathrm{pH}<3$ in which in this condition the alginate component will be stable in the raw material during the immersion process. While immersion in alkaline solutions was aimed for deproteinization (Kamaruddin et al. 2015).

\section{Extraction}

The brown seaweed extraction process was carried out in alkaline conditions. The goal was to separate the cellulose content from alginate. The extracting material that can be used is $\mathrm{Na}_{2} \mathrm{CO}_{3}$ or $\mathrm{NaOH}$. Lee and Mooney (2012) state that high concentrations of $\mathrm{Na}_{2} \mathrm{CO}_{3}(3-5 \%)$ can cause a decrease in product yield and viscosity. This is because the alkaline solution can damage the alginic acid compound by shortening the polymer chain into oligosaccharides which in turn degrades to 4-deoxy-5-ketouronic acid. Extraction carried out by heating will also affect the alginate produced. This heating process not only makes extraction processes easier but can also extract the weight of higher alginate molecules so that they can increase product yield and viscosity.

\section{Deposition of Na-alginate}

In the formation of sodium alginate, alginic acid that had been formed was added with alkaline solution containing Na+ions such as $\mathrm{NaOH}$ and $\mathrm{Na}_{2} \mathrm{CO}_{3}$. The purpose of the formation of sodium alginate is to get a more stable alginate compound. According to Mc Hugh (1987), the exchange of H+ions with $\mathrm{Na}+$ ions runs slowly depending on the alkali speed penetrating into the particles of alginic acid.

\section{Withdrawal of sodium alginate}

Withdrawal of Na-alginate compounds from sodium alginate solution can be done using alcohol. Alcohol commonly used is methanol (methyl alcohol) or isopropanol (isopropyl alcohol). According to Anonym (1976), $1 \%$ sodium alginate starts to show the separation process in a solution of 10\% isopropanol or in ethanol 20\% as well as its boiling point. The melting point of isopropanol (secondary alcohol) is lower than ethanol (primary alcohol). To withdraw sodium alginate, the use of isopropanol is more efficient than ethanol. Formation of pure sodium alginate was done by attracting the water content contained in the solution. This pure Na-alginate was then dried in an oven and after that, it can be ground into Na-alginate flour.

After the water content contained in the anatomic alginate solution was pulled out, pure sodium alginate was formed. Sodium alginate was then dried in an oven and ground to form sodium alginate flour. The characteristics of alginic acid and sodium alginate were tested compared to Table 1. Characteristics of alginic acid and sodium alginate and Table 2. Quality specifications of alginic acid and sodium alginate. According to Glicksman (1983), alginic acid is described as a hydrophilic colloidal carbohydrate extracted with alkali salt from various types of brown seaweed. Chemically, alginate is a pure polymer of uronic acid arranged in a long linear chain. The chemical formula of alginate is $\left(\mathrm{C}_{6} \mathrm{H}_{8} \mathrm{O}_{6}\right) \mathrm{n}$ with the number $\mathrm{n}$ between 80 to 83 (Schoeffel and Link 1993). There are two types of monomers that make up alginic acid, namely $\beta$-Dmannopyranosyl uronate or D-mannuronic acid and $\alpha-\mathrm{L}$ glucopyranosyl uronate or L-guluronic acid. Of the two types of monomers, alginic acid can be a homopolymer 
consists of similar monomers namely D-mannuronic acid only or L-guluronic acid only. Homopolymers of Dmannuronic acid (poly mannuronic acid) are formed by repeating D-mannuronic acid with $\beta-(1,4)$ bonds and hydrogen bonds between hydroxyl groups on $\mathrm{C} 3$ atoms with oxygen atoms on adjacent hexose rings. The homopolymer form of L-guluronic acid is more rigid than D-mannuronic acid homopolymer (Rajendran et al. 2016) Alginate with a high proportion of L-guluronic acid homopolymers tends to form stiff, rigid and syneresis gels. On the other hand, the higher proportion of D-mannuronic acid homopolymers tends to form a gel that is more elastic, does not rigid and does not show high syneresis (Glicksman 1983).

\section{Data analysis of molecular structure and quality of alginate}

Variables observed in alginate included yield test, moisture content test, ash content test, viscosity test, $\mathrm{pH}$ test and structural tests with FTIR. Alginate is a compound contained in brown seaweed cell walls (Phaeophyceae) other than cellulose and pectin.

\section{Rendement}

The Na-alginate yield obtained from the extraction process of seaweed Sargassum polycystum was calculated based on the weight of Na-alginate after drying on the dry weight of the raw material. The yield of Na-alginate was calculated using the following formula:

Addendum $(\%)=($ weight of Na-final alginate $(\mathrm{g}) /$ weight of initial seaweed $(\mathrm{g})) \times 100 \%$

\section{Viscosity}

Viscosity analysis referred to JECFA (2007). Observations were made at a $1-5 \%$ solid concentration to determine the relationship between concentration and solution viscosity. Na-alginate (sample) was weighed as much as $7.5 \mathrm{~g}$ in weigh paper. As much as $492.5 \mathrm{~g}$ of distilled water was weighed in a $500 \mathrm{~mL}$ glass beaker so that the sample and distilled water had total weight of 500 g. Alginate was included in a $500 \mathrm{~mL}$ glass beaker containing distilled water and stirred gradually. Aquades was heated and stirred once to reach $75^{\circ} \mathrm{C}$, after a constant temperature the solution was heated for 25 minutes. Stirring I was carried out at minute 1 for 1 minute, stirring II at 25 minutes. Beaker glass was covered with aluminum foil to prevent water loss in the heating process due to evaporation, then the solution temperature was lowered to reach $75^{\circ} \mathrm{C}$. The measurement of solution viscosity was measured using RVA (Rapid Visco Analyzer) spindle 2 at $30 \mathrm{rpm}$, waited until the spindle needle was stable (up to 6 times rotation). Viscosity is expressed in centipoise (cP).

\section{Water content}

A sample of $2 \mathrm{~g}$ was weighed and then put into a porcelain cup. The sample was heated by oven at temperature $105^{\circ} \mathrm{C}$ for 24 hours and keep the sample in the desiccator for 5 minutes. Finally, the sample was weighed until the value was stable. Water content was calculated using the following formula:
Water content $(\%)=($ weight of final sample $(\mathrm{g}) /$ weight of initial sample (g)) x 100\%

\section{Ash content}

The final sample from water content continued to be heated using ignition furnace at temperature $600^{\circ} \mathrm{C}$ for 24 hours. Then the sample was kept in the desiccator for 5 minutes. Finally, the sample was weighed until the value was stable. Ash content was calculated using the following formula:

Ash content $(\%)=($ weight of final ash sample $(\mathrm{g}) /$ weight of initial sample (g)) x 100\%

\section{pH value}

A sample of $3 \mathrm{~g}$ was weighed and then put into a 300 $\mathrm{mL}$ glass beaker then added $197 \mathrm{~g}$ of distilled water until the total weight was $200 \mathrm{~g}$. The sample was heated while being stirred using a stirrer until it dissolved at a temperature of $60-80^{\circ} \mathrm{C}$. Then the electrode was dipped into the sample solution which was previously calibrated. The $\mathrm{pH}$ value was obtained according to what shown on the screen. Then the electrode was rinsed with distilled water.

\section{Alginate partial hydrolysis test}

The composition of poly guluronic, poly mannuronate and mixed segments between mannuronate and guluronate in alginate determine the quality of alginate (Gomez 2018). To isolate mannuronic acid (M) and guluronate $(\mathrm{G})$ on alginate molecules, we carried out Partial Hydrolysis of Alginate by $5.00 \mathrm{~g}$ alginate in $\mathrm{HCl} 0.3 \mathrm{~N}$ at $100^{\circ} \mathrm{C}$ for 2 hours. The soluble fraction was identified as a block MG. Bonding the hydroxyl between $\mathrm{M}$ and $\mathrm{G}$ was easily hydrolyzed by insoluble-fraction acid more resistant to acid hydrolysis, again dissolved by adding alkali and fractionation by adjusting the $\mathrm{pH}$ at 2.85 , so that the GG block settled and the MM block dissolved.

Analysis of alginate functional groups was carried out using a Fourier Transform Infrared (FTIR) spectrophotometer (Perkin Elmer, spectrum one) based on the method of van Rossum (2000). Samples plus KBr (1: 100) was then mashed until evenly mixed. Then it was pressed with a vacuum pump for 15 minutes, and read the absorbance at wavelengths of $400-4000 \mathrm{~cm}^{-1}$. From the resulted curve, the type of bond and its functional group were determined based on FTIR references.

\section{FTIR Analysis}

As much as $2 \mathrm{mg}$ of alginate sample was put into a small bottle and $200 \mathrm{ml} \mathrm{KBr}$ was added, then stirred until homogeneous. The mixture was then placed on the die, pressed for several minutes until it formed pellet. The pellets were then put into the sample and their absorption was measured at 4000-400nm wavelength. Alginate was at peak at wavelength $1030 / 1080 \mathrm{~nm}$. 


\section{RESULTS AND DISCUSSION}

\section{Characteristics of seaweed}

Raw materials of Sargassum polycystum obtained from Lima island, Ujung Kulon and Binuangeun of from western Java are presented in Figures 5, 6, 7. Analysis of the quality of Sargassum polycystum seaweed from those three locations which includes yields, water content, CAW, and impurities is shown in Table 3.
The yields of dried seaweed differ across the three locations with the highest yield of Sargassum polycystum was from Binuangeun with $25.77 \%$. Overall, the water content of all samples is below $15 \%$. According to Winarno (1996), the water content of seaweed is influenced by the drying process. The highest water content was found in the sample from Ujung Kulon with $14.50 \%$ but this still meets the requirements by the SNI standard.
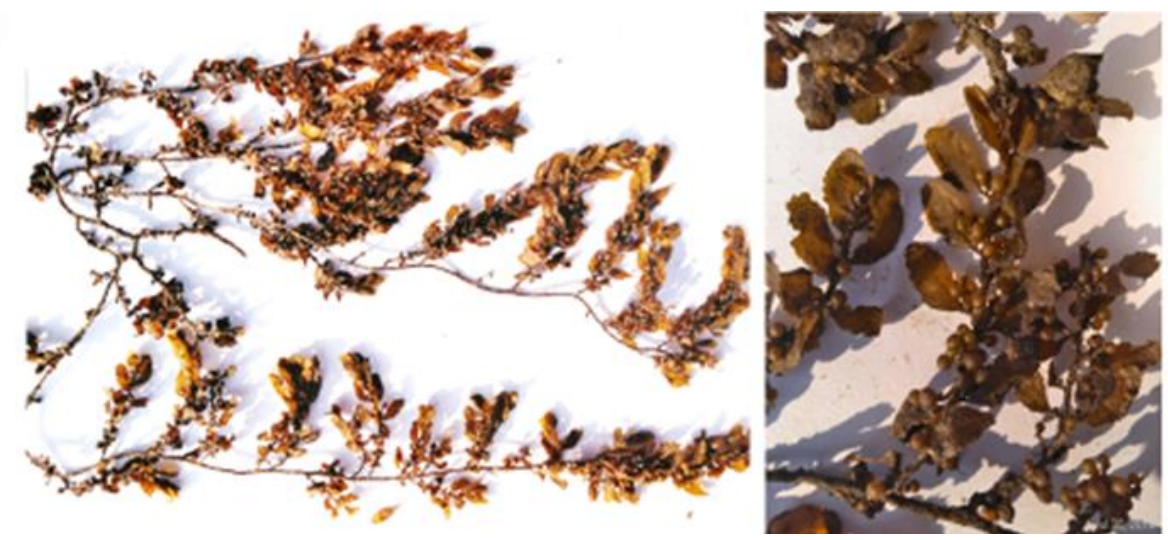

Figure 5. Sargassum polycystum seaweed from Lima Island, Banten Province, Indonesia
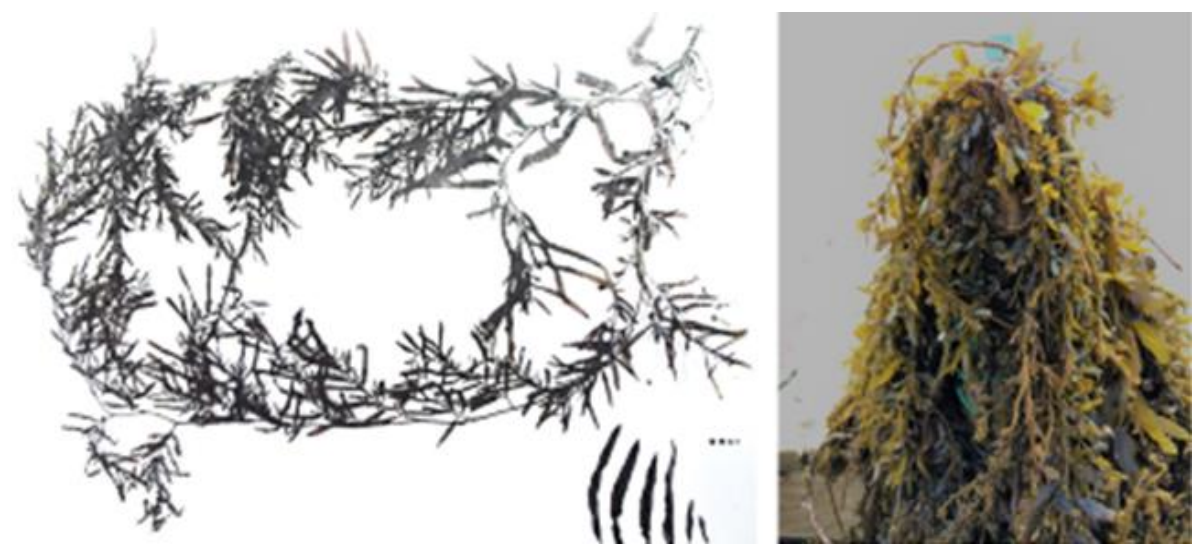

Figure 6. Sargassum polycystum seaweed from Ujung Kulon, Banten Province, Indonesia
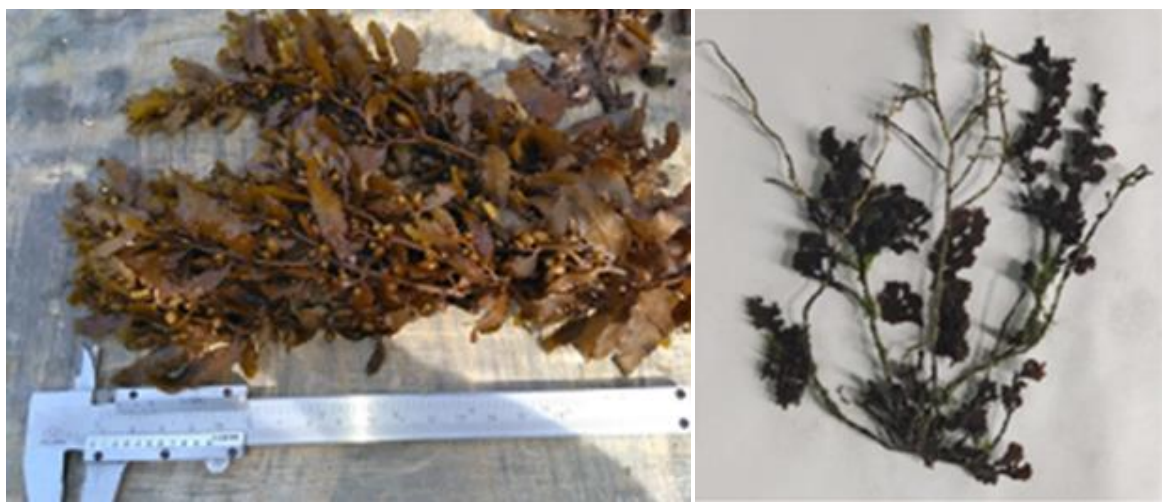

Figure 7. Sargassum polycystum seaweed from Binuangeun, Banten Province, Indonesia 
Table 3. Chemical composition of Sargassum polycystum seaweed from three locations in Banten, Indonesia

\begin{tabular}{lcccccccccc}
\hline \multirow{2}{*}{ Chemical composition } & \multicolumn{3}{c}{ Lima Island } & \multicolumn{3}{c}{ Ujung Kulon } & \multicolumn{3}{c}{ Binuangeun } & Standard \\
\cline { 2 - 10 } & $\mathbf{1}$ & $\mathbf{2}$ & Mean & $\mathbf{1}$ & $\mathbf{2}$ & Mean & $\mathbf{1}$ & $\mathbf{2}$ & Mean & - \\
\hline Rendement (\%) & 12.96 & 11.22 & 12.09 & 17.78 & 14.70 & 16.24 & 29.54 & 22.00 & 25.77 & - \\
Water content (\%) & 09.00 & 09.50 & 09.25 & 12.75 & 11.00 & 11.88 & 13.00 & 12.50 & 12.75 & $<15 \%$ \\
CAW (\%) & 76.64 & 71.49 & 74.06 & 67.69 & 65.42 & 66.55 & 75.59 & 78.24 & 76.92 & $>50 \%$ \\
Impurities (\%) & 13.80 & 09.32 & 11.56 & 33.88 & 3.50 & 3.69 & 25.27 & 26.15 & 25.71 & $20-30 \%$ \\
\hline
\end{tabular}

Table 4. The mean value of physical quality analysis of $\mathrm{Na}$ alginate extracted from Sargassum polycystum collected from three locations in Banten, Indonesia

\begin{tabular}{|c|c|c|c|c|}
\hline \multirow{2}{*}{ Characteristics } & \multicolumn{3}{|c|}{ Site } & \multirow[b]{2}{*}{ Standard } \\
\hline & Lima Island & Ujung Kulon & Binuangeun & \\
\hline Rendement (\%) & $11.48+0.79$ & $18.62+0.84$ & $05.75+0.11$ & $>18.00 *$ \\
\hline Viscosity $(\mathrm{cP})$ & $35.00+7.07$ & $62.50 \pm 3.53$ & $81.33+1.88$ & $>27.00 * *$ \\
\hline
\end{tabular}

Note: BSN (2015)* and ** Food Chemical Codex (2004)

CAW provides information on the cleanliness of seaweed from dirt, sand, and rock attached. Based on Table 2 , it can be seen that the CAW values of the samples from Lima Island, Ujung Kulon and Binuangeun were 76.64\%, $67.69 \%$, and $75.59 \%$, respectively. These values mean that the samples of Sargassum polycystum were clean and free of dirt. These results are in accordance with the quality requirements of dried seaweed based on SNI No. 2690.1.2015 which suggest minimum value of $50 \%$ (BSN 2015).

The highest impurity level of the three locations was from Binuangeun $(25.71 \%$ ) in which the samples contain sand, rock, coral and the wastes produced by humans including plastic as Binuangeun is close to residential dwellings. Impurity rate of Sargassum polycystum from Lima Island was $11.56 \%$, consisting of sand and coral. The lowest impurity level was from Ujung Kulon (3.69\%), indicating the cleanest samples which contain sand and coral as the sampling location was far from the residential areas of Taman Jaya village, Sumur Sub-district, Pandeglang District, Banten Province.

\section{Alginate extraction}

The physical characteristics of the quality of $\mathrm{Na}$ alginate Sargassum polycystum from three locations are presented in Table 4.

\section{Rendement}

Sargassum polycystum from Ujung Kulon has the highest $\mathrm{Na}$ alginate content $(18.62 \%+0.84 \%)$ followed by that from Lima Island with an average $11.48 \%+0.79 \%$ which is likely influenced by the cleanliness of the location which consists only of sand and coral. In contrast, samples from Binuangeun has the lowest $\mathrm{Na}$ alginate yield $(5.75 \%+0.11 \%)$ which might be influenced by the amount of sand, rock, coral and litter contained because it is close to human settlement. The results of the alginate yield test in the extraction of Sargassum polycystum are presented in Figure 8.

Alginate yield produced by seaweed is influenced by habitat (i.e. light intensity, sea currents, and aquatic nutrition), age of brown seaweed, the handling techniques of brown seaweed during collection, and the extraction process used (Basmal et al. 2012). Because this study used the same treatment across three locations, so habitat and sea currents are likely the influencing factors on the yield of alginate. Binuangeun has shallow water with depth of $40.00 \mathrm{~cm}$ and the shortest total thallus length was $31.82 \mathrm{~cm}$ where Sargassum overgrew at the lowest ebb in the form of inundation affected by current velocity $(0.24,0.14$, and 0.03). Based on the Meteorological, Climatology and Geophysics Agency (BMKG-maritime.bmkg.go.id) waves in the area of Lima Island are classified as Slight Sea/Small group with wave size of 0.5-1.25 m, while in Ujung Kulon and Binuangeun are belong to Moderate Sea/Moderate group with wave size of 1.25-2.50. This condition causes the thallus length of Sargassum polycystum in Binuangeun to be shorter than that in Ujung Kulon and Lima Island.

\section{Viscosity}

The highest mean viscosity was Sargassum polycystum originating from Binuangeun $(81.33+1.88) \mathrm{cP}$, followed by that from Ujung Kulon $(62.50+3.53) \mathrm{cP}$, and Lima Island $(35.00+7.07) \mathrm{cP}$. The high content of water-insoluble material and low alginate viscosity is caused by the low purity of the alginate produced. Na-alginate thickness is divided into three levels, namely low viscosity $(<60 \mathrm{cP})$, medium viscosity (60-110 cP) and high viscosity (110-800 $\mathrm{cP}$ ). Based on this division, the viscosity of $\mathrm{Na}$ alginate from Lima Island is categorized as low viscosity (Manev et al. 2015). Sodium alginate for food usually has a lower viscosity than sodium alginate for textiles. Seaweed from the tropics (warm water) generally produces alginates with low viscosity (Mc Hugh 2008). Seaweed with a long thallus length will produce $\mathrm{Na}$ alginate with low viscosity, 
whereas if used with seaweed with a short thallus (20-40) $\mathrm{cm}$ it will produce high viscosity. Possible differences in the location where it grows is one of the causes of the difference in the value of the resulting viscosity (Hamrun 2018). The results of the alginate viscosity extracted from Sargassum polycystum are presented in Figure 9.

Alginate viscosity is influenced by several factors, including temperature, solution level and degree of polymerization. $\mathrm{Na}$ alginate viscosity value is highly dependent on the age of brown seaweed when harvested, extraction techniques (concentration, temperature, $\mathrm{pH}$ and the presence of polyvalent metal cations) and the weight of seaweed molecules extracted (Mc Hugh 2008). The temperature at the time of making the solution for the analysis of viscosity Na-alginate should not exceed $80^{\circ} \mathrm{C}$, if it exceeds this temperature the solution will be degraded so that it is difficult to analyze the thickness using RVA (Rapid Visco Analyzer). Anggadiredja 2011 stated that the higher is the drying temperature, the higher is the viscosity value. It is assumed that the increase in drying temperature will increase the formation of the amount of sulfate esters so that viscosity increases.

\section{Chemical characteristics of Na-alginate Sargassum polycystum}

Chemical analysis of Na-alginate extracted from Sargassum polycystum including the value of water content, ash content, and $\mathrm{pH}$ value are presented in Table 5. Sargassum polycystum seaweed from Binuangeun has $\mathrm{Na}$ alginate with higher water content and ash content than that from Lima Island and Ujung Kulon, while the mean $\mathrm{pH}$ $(6.05+0.57)$ is lower.

\section{Water content}

Drying is a process of reducing a part of the water content of the material. Water content of the material is the amount of water contained in the material expressed in percent (\%). The water content in $\mathrm{Na}$ alginate from the three study locations was in accordance with international quality standards in which the drying losses were $<15 \%$ (FCC 2004). The mean water content of $\mathrm{Na}$ alginate seaweed Sargassum polycystum from the three study locations is presented in Table 5. The results of the observations showed that the mean value of $\mathrm{Na}$ alginate water content from Binuangeun was the highest. The higher the purity of alginate results in the difficulty of the water coming out of the matrix during the drying process. Alginate is a polymer with the ability to hold water very well so that the higher the purity of the alginate, the better the ability to hold water (Lee and Mooney 2011).

Water is an important component in food ingredients because water can affect the appearance, texture, and taste of food. The water content in food ingredients also determines acceptability and diversity as well as durability of food ingredients. The water content allowed in $\mathrm{Na}$ alginate is between 5-20\%, while the water content allowed by the FCC is $<15 \%$. When compared to some research standards, water content of Na-alginate meets the standard (FCC 2004). JECFA also stated that the water content of food additives of alginate is maximum at $15 \%$ (FAO 2009).

\section{Ash content}

Ash content is important to know because it can determine the purity level of the product from unwanted components (Chee et al. 2011) . Based on the analysis it can be seen that commercial alginate generally has a maximum ash content of $27 \%$. This means that alginate extracted from the three locations still meets JECFA requirements standards in term of the ash content contained (Mc Hugh 1987).

$p H$

$\mathrm{Na}$ alginate extracted from Binuangeun with a mean $\mathrm{pH}$ of 6 was lower than the $\mathrm{pH}$ of Ujung Kulon and Lima Island. The results of the overall chemical and physical analysis suggest that $\mathrm{Na}$ alginate produced from Binuangeun is more suitable for non-food products as this is related to the quality produced. The results from Binuangeun have brighter color which can be formulated according to the needs and desired physicochemical properties, especially those related to gel formation, thickness, binding of water so that it can retain moisture. On the other hand, $\mathrm{Na}$ alginate produced from Lima Island is more suitable for food products. Alginate for food must have low water content, low ash content and neutral $\mathrm{pH}$ (Puspita 2017). Alginate characteristics extracted from Sargassum polycystum from Lima Island, Ujung Kulon and Binuangeun meet alginate standards as food grade, but the alginate from Binuangeun has high level of viscosity according to the needs of the non-food industry.

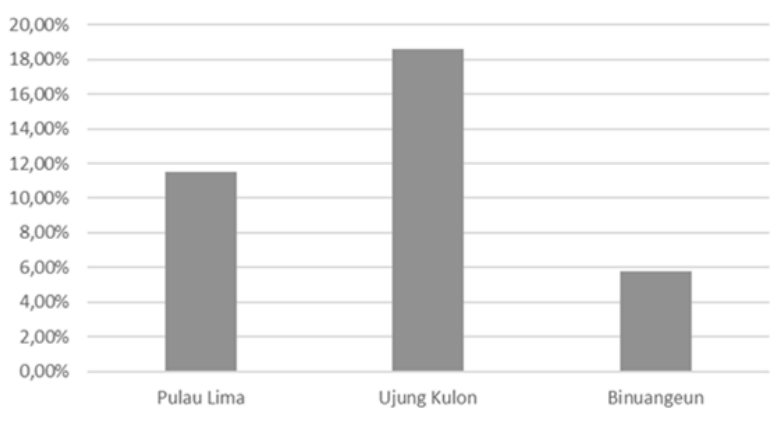

Figure 8. Results of alginate yield test in extraction of Sargassum polycystum $(\%)$

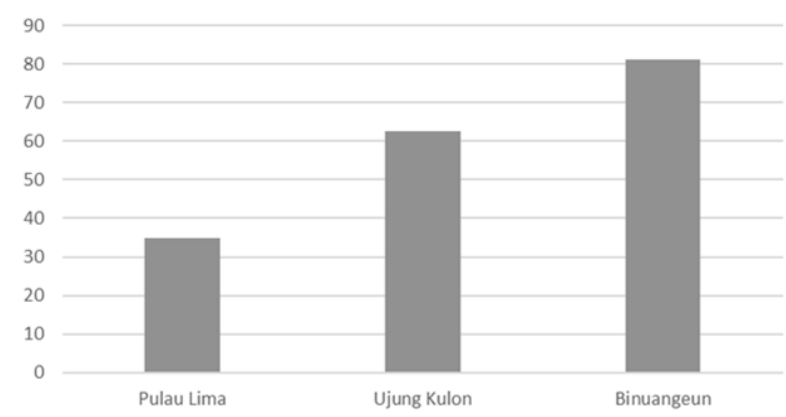

Figure 9. Test results for alginate viscosity in extraction of Sargassum polycystum (cP) 
Table 5. Mean value of chemical quality analysis of Na alginate Sargassum polycystum from three locations in Banten, Indonesia

\begin{tabular}{lcccc}
\hline \multirow{2}{*}{ Characteristics } & \multicolumn{3}{c}{ Locations } \\
\cline { 2 - 5 } & Lima Island & Ujung Kulon & Binuangeun & Standard* \\
\hline Water content $(\%)$ & $12.42+0.30$ & $10.23+1.68$ & $13.31+0.77$ & $5-20$ \\
Ash content $(\%)$ & $26.68+2.48$ & $24.94+4.41$ & $26.69+0.82$ & $18.00-27.00$ \\
pH & $7.39+0.03$ & $7.03+2.60$ & $6.05+0.57$ & $3.5-10$ \\
\hline
\end{tabular}

Note: * Food Chemical Codex (2004)

Table 6. Results of alginate partial hydrolysis

\begin{tabular}{lccccc}
\hline Locations of Sargassum spp. & Blok GG & Blok MM & Blok MG & Blok M & Blok G \\
\hline Pulau Lima & 67.60 & 27.00 & 5.40 & 30 & 70 \\
Ujung Kulon & 59.00 & 35.00 & 6.00 & 37 & 63 \\
Binuangeun & 41.40 & 50.00 & 9.60 & 55 & 45 \\
\hline
\end{tabular}

Table 7. Functional groups on the FTIR curve

\begin{tabular}{lcccl}
\hline \multirow{2}{*}{ Wavelength $\left(\mathbf{c m}^{-1}\right)$} & \multicolumn{3}{c}{ \% Transmitan $(\% \mathbf{T})$} & \\
\cline { 2 - 4 } & Pulau Lima & Ujung Kulon & Binuangeun & \multirow{2}{*}{ Functional groups } \\
\hline $3427.51-3448.72$ & 63.29 & 53.88 & 62,80 & O-H stretching (hydrogen bonds between molecules) \\
1608.63 & 50.98 & 41.15 & 50.29 & C=O stretching \\
1411.89 & 38.72 & 33.42 & 38.49 & -C-OH stretching \\
$1091-1093.64$ & 53.62 & 41.02 & 48.50 & COOH, C-O stretching, C-O-C stretching \\
1170 & 64.41 & 48.21 & 56.67 & C-O stretching, C-C stretching, C-C-C bending \\
$1029.99-1033.85$ & 48.94 & 37.16 & 45.59 & C-O stretching, C-O-C stretching \\
947.05 & 62.31 & 47.11 & 54.50 & C-O stretching, C-C-H stretching \\
$817.82-875.68$ & 39.92 & 30.96 & 35.04 & C-C stretching, C-C-H stretching, C-O bending \\
\hline
\end{tabular}

\section{Partial hydrolysis of alginate}

The results of isolation of mannuronic acid (M) and guluronate $(\mathrm{G})$ on alginate molecules were carried out by partial hydrolysis of alginate, obtained by GG block deposits as presented in Table 6. The highest component of $\mathrm{G}$ in alginate is obtained from Lima Island with the results of viscosity test as listed in Figure 8 and according to the functional group analysis which is qualitatively proven on the FTIR curve as shown in Figure 10.

\section{Analysis of functional groups of sodium alginate from} extraction of Sargassum polycystum from three locations

Uptake of functional groups from $S$. polycystum from three locations can be seen in the FTIR curve presented in Figure 10 and Table 7 . The sodium alginate spectrum showed the presence of hydroxyl $(-\mathrm{OH})$ groups, carbonyl groups (-COO-),-C-OH and-COOH bonds, C-O stretching, $\mathrm{C}-\mathrm{C}$ stretching, and $\mathrm{C}-\mathrm{O}$ bending as seen in FTIR curves (Figure 10). According to Alvares et al. (2018), absorption at wavelengths of $1608.63 \mathrm{~cm}^{-1}, 1411.89 \mathrm{~cm}^{-1}$ and 1091 $\mathrm{cm}^{-1}-1093.64 \mathrm{~cm}^{-1}$ (in the wavelength area $1091 \mathrm{~cm}^{-1}$ $1093,64 \mathrm{~cm}^{-1}$, if higher than absorption at wavelength 1029 $\mathrm{cm}^{-1}-1033 \mathrm{~cm}^{-1}, 947 \mathrm{~cm}^{-1}$ and 817,82 $\mathrm{cm}^{-1}-875,68$ (at the wavelength area of $1029 \mathrm{~cm}^{-1}$ to $817 \mathrm{~cm}^{-1}$ ) indicates that the alginate polymer consists of a higher proportion of guluronic monomers, whereas absorption at wavelengths of $1315 \mathrm{~cm}^{-1}, 1170 \mathrm{~cm}^{-1}, 1029 \mathrm{~cm}^{-1}-1033 \mathrm{~cm}^{-1}, 947 \mathrm{~cm}^{-1}$ and $817.82-875.68 \mathrm{~cm}^{-1}$ were higher indicating that the alginate polymer consisted of the proportion of mannuronic monomers.

In the results of the FTIR curve showed that the absorption at wavelength $1608.63 \mathrm{~cm}^{-1}, 1411.89 \mathrm{~cm}^{-1}$, and $1091 \mathrm{~cm}^{-1}-1093.64 \mathrm{~cm}^{-1}$ in Binuangeun alginate products provide higher absorption compared to Lima Island and Ujung Kulon alginates. However, the results of the GG block partial deposit test (Table 8) showed that alginate extracted from Binuangeun had the lowest guluronate group (41.40\%). This is possible at wavelength of 1029.99 $\mathrm{cm}^{-1}-1033.85 \mathrm{~cm}^{-1}$ giving quite high uptake of $\mathrm{C}-\mathrm{O}$ stretching and C-O-C stretching. Whereas, Lima Island and Ujung Kulon alginate products showed a higher proportion of guluronate monomers than mannuronate. According to the quantitative test of GG block, partial deposits for Lima Island, Ujung Kulon and Binuangeun resulted in $67.60 \%$, $59.00 \%$, and $41.40 \%$, respectively. 


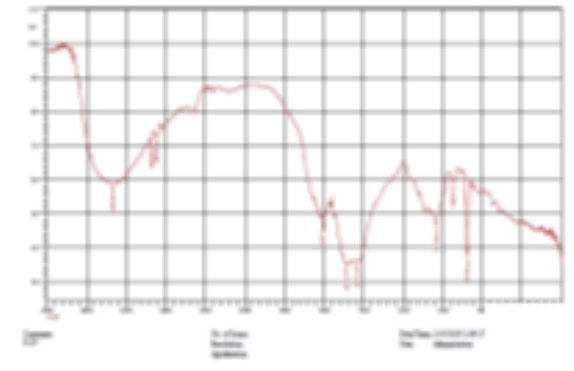

A

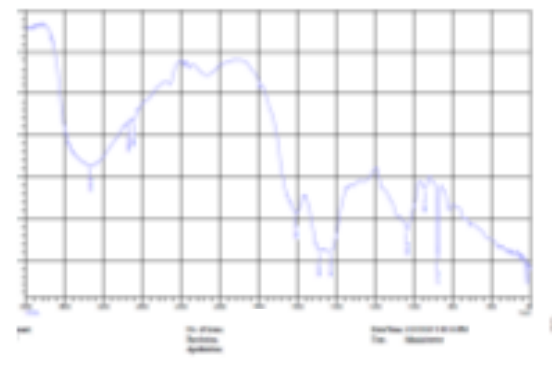

B

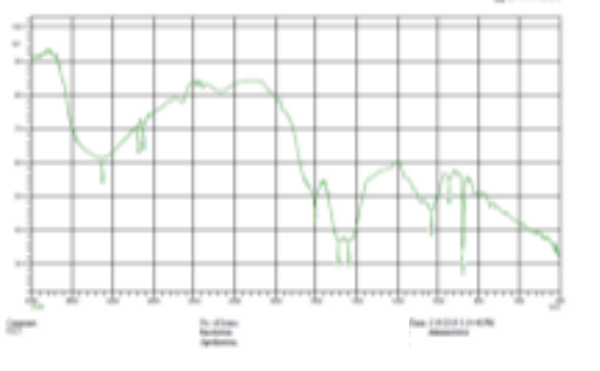

C

Figure 10. FTIR curve of alginate: A. Lima Island, B. Ujung Kulon, C. Binuangeun

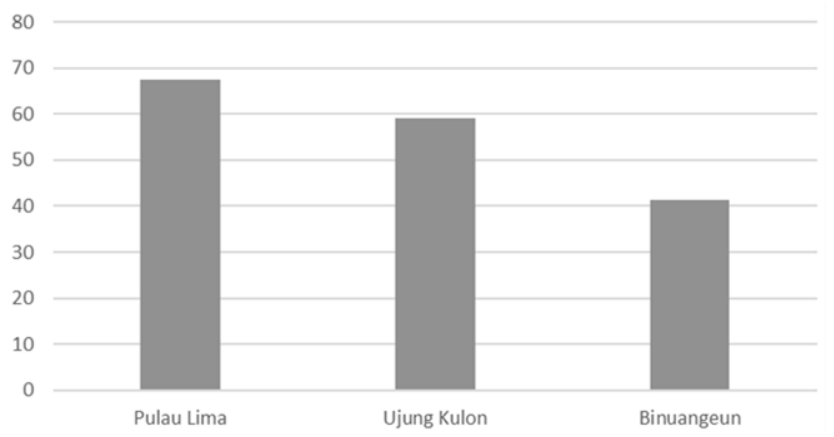

Figure 11. Results of GG block deposition test on alginate structure $(\%)$

In conclusion, the combination of viscosity and gel strength of guluronate and mannuronate is the determinant factors to produce hydrogel than other characteristics, while the other characters are supporting ones. The results of this study showed that the yields of alginate from Sargassum polycystum from Lima Island, Ujung Kulon and Binuangeun were $11.48 \%, 18.62 \%$, and $5.75 \%$, respectively. Alginate from Binuangeun has the best physicochemical characteristics compared to the others. The viscosity of alginate from Lima Island, Ujung Kulon and Binuangeun were $35 \mathrm{cP}, 62.50 \mathrm{cP}$, and $81.33 \mathrm{cP}$, respectively. The characteristics of $\mathrm{Na}$ alginate extracted from Binuangeun have relatively higher quality. Alginate characteristics extracted from Lima Island, Ujung Kulon and Binuangeun have met alginate standards as food grade, but when viewed from viscosity, Binuangeun has the highest viscosity according to the needs of the non-food industry. The results of the partial alginate hydrolysis test showed that guluronic block (GG) in alginate polymers on the Lima Island, Ujung Kulon and Binuangeun were $67.60 \%, 59.00 \%$, and $41.40 \%$, respectively. This is related to the gel properties formed. Alginate from Lima Island tends to be stiffer and less flexible than alginate from Ujung Kulon and Binuangeun. Our study showed that there were variations in the concentration of mannuronate and guluronate from the three habitats of Sargassum in Banten.

\section{ACKNOWLEDGEMENTS}

We thank Ms. Petra Spliethoff and the NICHE Project CDI Team (Center for Development Innovation), Wageningen University \& Research, Netherlands who have provided doctoral scholarship assistance at the University of Indonesia, Depok. We also thank Research Center for Oceanography, LIPI, Jakarta, Research Center for Biology, LIPI, Cibinong, Bogor, Research Center for Fisheries Biotechnology and Processing, KKP, Jakarta, KKP Loka Ujung Kulon, TPI Binuangeun, BAPPL Karangantu, Biology, Environment, Chemistry and Biotechnology Laboratory of STP, Jakarta, Molecular-Biology and Chemistry Laboratory of FMIPA UI and ILRC UI Jakarta which have helped carry out this research

\section{REFERENCES}

Badan Standarisasi Nasional [BSN]. 2015. SNI Rumput Laut Kering no 2690.1.2015. BSN, Jakarta. [Indonesian]

Chee SY, Wong PK, Wong CL. 2011. Extraction and characterization of alginate from brown seaweed (Fucales, Phaeophyceae) collected from Port Dickson, Peninsular Malaysia. J Appl Phycol 23: 191-196.

FAO. 2009. The State of Food and Agriculture. Food and Agriculture Organization of the United Nations, Rome.

FCC. 2004. Food Chemical Codex. 4th ed. Volume III. Food Chemical Codex, National Academy of Science, Washington D.C.

Glicksman M.1983. Food Hydrocolloid. CRC Press, Boca Raton, FL.

Gomez FM, Guerrero J, Matsuhiro B, Paves J. 2018. Characteristics of poly-D-mannuronate and poly-L-guluronate block fractions from sodium alginate and preparation of hydrogels with poly King (vinylalcohol). Intl J Biol Macromol 111: 935-946.

Hamrun N, Thalib B, Tahir D, Kasim S, Nugraha AS. 2018. Physical characteristics test (water content and viscosity) of extraction sodium alginate brown algae (phaeophyta) species padina sp. as basic material for production dental impression material. J Dentomaxillofacial Science 3: 84 -87.

Inoue A. 2018. Characterization of PL-7 Family alginate lyases from marine organisms and their applications. Methods in Enzymology 605: 499-524. Elsevier, Nederlands.

JECFA. 2007. Compendium of Food Additive Specification. Joint FAO/WHO Expert Committee on Food Additives, FAO-UN, Rome.

Kamaruddin MA,Yusoff MS, Azi HA. 2014. Preparation And Characterization Of Alginate Beads By Drop Weight. Intl J Technol 2: 121-132. 
Kustiningsih et al. 2019 Extraction and characterization of semi refined carrageenan of red algae originated from Lontar beach. AIP Conference Proceedings 2085 (1). DOI: 10.1063/1.5095014

Lee KY, Mooney DJ. 2012. Alginate: properties and biomedical applications. Prog Polym Sci. 37 (1): 106-126.

Manev Z, Denev P, Petkova NT, Ludneva D. 2015. Investigation the influence of dietary fiber on the rheological properties of alginate beads. J Agric Sci Technol 7 (1): 137-140.

Mc Hugh DJ. 1987. Production, properties and uses of alginates. In McHugh DJ. (ed.). Production and Utilization of Products from Commercial Seaweeds. FAO Fish Tech Pap 288: 58-115. Campbell, Australia.

Pereira L. 2018. Seaweeds as source of bioactive substances and skin care therapy-cosmeceuticals, algotheraphy, and thalassotherapy. Cosmetics 5: 68. DOI: 10.3390/cosmetics5040068.

Puspita M. 2017. Enzyme-Assisted Extraction of Phlorotannins from Sargassum and Biological Activities. Diponegoro University, Semarang \& Université Bretagne Sud, France.
Rajendran S, Anand SC, Rigby AJ. 2016. 5 - Textiles for healthcare and medical applications. Handbook of Technical Textiles 2: 135-168.

Rasyid A. 2007. Sodium alginate extraction of Padina australis. Oseanologi dan Limnologi di Indonesia 33 (2): 271-279. [Indonesian] Setyawidati NAR, Puspita M, Kaimuddin AH, Widowati, Deslandes E, Bourgougnon N, Stiger-Pouvreau V. 2018. Seasonal biomass and alginate stock assessment of three abundant genera of brown macroalgae using multispectral high-resolution satellite remote sensing: A case by study Ekas bay (Lombok, Indonesia). Mar Pollut Bull 131: 40-48.

Silva M, Gomes F, Oliveira F, Morais S, DelerueMatos C, 2015. Microwave-assisted alginate extraction from Portuguese saccorhiza polyschides- influence of acid pretreatment. Intl J Chem Nuclear Mater Metallurg Eng 9 (1): 30-33.

Widyartini DS, Widodo P, Susanto AB. 2017. Thallus variation of Sargassum polycystum from Central Java, Indonesia. Biodiversitas 18 (3): 1004-1011 